\title{
Flower Extracts of Cage Plants (Canavalia virosa) as an Indicator of Acid Base
}

\section{*Andi Moh. Rendi, Supriadi \& Suherman}

Pendidikan Kimia/FKIP - Universitas Tadulako, Palu - Indonesia 94119

Received 4 September 2020, Revised 8 October 2020, Accepted 6 November 2020

doi: 10.22487/j24775185.2020.v9.i4.pp191-198

\begin{abstract}
Cage plants (Canavalia virosa) are classified as nuts. This study aims to prove the flowers of the cage plants as acid-base indicators and determine the type of acid-base titration that is suitable for indicators of cage plants. The flowers of the cage plants were macerated with ethanol. Extras were tested as indicators in acid-base solutions, buffer solutions, and compared with phenolphthalein and methyl orange for acid-base titration, namely: strong acid with a strong base, a weak acid with a strong base, and weak base with strong acid. The results obtained in this study, namely: flower extracts of cage plants in strong red acid, in weak acid pink, in strong green bases, and weak bases in light green. In a buffer solution of $\mathrm{pH} 1$ to $\mathrm{pH} 11$, the flower extract of the cage plants gives 4 color groups, namely: a buffer solution with $\mathrm{pH} 1$ colored red, $\mathrm{pH} 3$ colored pink, $\mathrm{pH} 5$ to $\mathrm{pH} 9$ being light green, and pH 11 being dark blue. Cage plant flower extract can be used as an indicator of acid-base, cage plant flower extract can be used on strong-base strong acid titration, strong weak-acid base, and weak-strong base acid titration.
\end{abstract}

Keywords: Cage plant flowers, extracts, indicators, acid-base

\section{Pendahuluan}

Indikator asam basa adalah suatu bahan yang dapat mengidentifikasi sifat asam dan basa suatu larutan. Apabila suatu bahan indikator diujikan terhadap larutan asam atau basa maka akan terjadi perubahan warna yang dapat membedakan sifat suatu larutan asam atau basa. Percobaan penguji suatu larutan asam atau basa umumnya menggunakan indikator sintetis antara lain kertas lakmus, fenolftalein (pp), metil merah dan brom timol biru. Salah satu bentuk indikator yang praktis dan mudah digunakan adalah kertas indikator fenolftalien (pp), atau dengan menggunakankertas lakmus merah dan biru.

Indikator alami dapat dibuat dari berbagai tumbuhan berwarna yang ada di sekitar kita.Akan tetapi, tidak semua tumbuhan berwarna dapat memberikan perubahan warna yang jelas pada kondisi asam maupun basa, oleh karena itu hanya beberapa saja yang dapat dipakai, misalnya; bunga sepatu yang memberikan perubahan warna merah pada suasana asam dan hijau pada suasana basa (Nuryanti, dkk., 2010), bunga mawar yang memberikan perubahan warna merah dan kuning (Maryanti, dkk., 2011), bunga waru yang memberikan perubahan warna merah dan hijau (Frantauansyah, 2013) dan bunga johar yang memberikan perubahan warna kuning dan orange (Kurniawati, dkk., 2015).

Indikator asam-basa dapat diperoleh secara langsung dari alam. Menurut Mulyono (2010) sumber indikator asam basa alami dapat berasal dari tanaman (akar, daun, bunga, buah, atau biji) dan dapat dibuat melalui ekstraksi dengan pelarut yang sesuai. Beberapa penelitian mengenai pemanfaatan ekstrak pigmen tanaman sebagai indikator asam basa telah dilakukan. Izonfuo (2006) melaporkan bahwa pigmen warna antosianin dari ekstrak tanaman rosella (Hibiscus sabdariffa) dan ekstrak tanaman binahong (Basella alba) dapat digunakan sebagai indikator pada titrasi asam basa. Bunga mawar yang memberikan perubahan warna merah pada suasana asam dan kuning pada suasana basa (Maryanti, dkk., 2011). Indikator ekstrak tanaman rosella (Hibiscus sabdariffa) memiliki trayek $\mathrm{pH}$ 3,79 - 7,70 dengan perubahan warna dari merah muda (asam) ke hijau (basa). Sedangkan ekstrak tanaman binahong (Basella alba) memiliki trayek pH 6,68 - 8,66 dengan perubahan warna dari merah muda (asam) ke hijau (basa). Seperti halnya tanaman berwarna tersebut, ekstrak bunga tanaman kerandang juga merupakan salah satu tanaman yang memiliki potensi untuk dijadikan indikator alami. Hal ini dikarenakan, antara kulit dari tanaman jantung pisang kepok mengandung senyawa pemberi warna pada tanaman yakni antosianin. Berdasarkan penelitian tentang indikator asam basa yang telah dilakukan oleh beberapa peneliti, dapat disimpulkan bahwa tanaman yang mengandung antosianin dapat dijadikan sebagai indikator asam basa alami serta dapat menggantikan indikator sintetik seperti metil orange (mo), fenolftalein (pp) dan metil merah (mm) (Nuryanti, dkk., 2010;

*Correspondence:

Andi Moh. Rendi

e-mail: rendi7707@gmail.com

(c) 2020 the Author(s) retain the copyright of this article. This article is published under the terms of the Creative Commons Attribution License 4.0, which permits unrestricted non-commercial use, distribution, and reproduction in any medium, provided the original work is properly cited. 
Agrawal, dkk., 2011; Abbas, 2012; Frantauansyah dkk, 2013, Irwan, 2014; Pimpodkar, dkk., 2014).

Ada beberapa indikator yang sering digunakan dalam praktikum kimia materi asam basa diantaranya adalah kertas lakmus, indikator universal, fenolftalein, metil merah, dan bromtimol biru (Indira, 2015). Indikator tersebut merupakan indikator sintesis (Hizbul dkk, 2008).

Antosianin merupakan pewarna alami yang tersebar luas dalam tanaman (bunga, buah-buahan, sayuran, dan umbi-umbian). Antosianin adalah bagian dari senyawa fenol yang tergolong flavonoid. Menurut Durst \& Wrolstad (2005) bahwa antosianin jumlahnya sekitar 90-96\% dari total senyawa fenol. Pigmen ini berperan terhadap timbulnya warna merah hingga biru pada beberapa bunga, buah dan daun. Senyawa antosianin stabil dan akan memberikan warna yang cerah pada $\mathrm{pH}$ asam dan akan kehilangan warnanya seiring dengan meningkatnya $\mathrm{pH}$. Kestabilan warna senyawa antosianin dipengaruhi oleh $\mathrm{pH}$ atau tingkat keasaman, dan akan lebih stabil apabila dalam suasana asam atau $\mathrm{pH}$ yang rendah (Arja, dkk.,2013).

Bunga tanaman kerandang dapat ditemukan disekitaran kampus Universitas Tadulako. Umumnya tanaman kerandang hanya sebagai tanaman liar. Tanaman kerandang memiliki beberapa jenis dimana pada jenis yang lain tanaman kerandang menghasilkan polong yang menggantikan kedelai untuk pembutan tempe. Oleh karena itu, peneliti merasa tertarik untuk memanfaatkan tanaman kerandang khususnya pada bunga yang berwarna ungu sebagai indikator alami dan diharapkan dapat berfungsi sebagai alternatif pengganti indikator sintetik fenolftalein dan metil orange.

Tulisan ini dimaksudkan untuk mendeskripsikan potensi bunga tanaman kerandang sebagai indikator alami dalam titrasi asam basa

\section{Metode}

Alat yang digunakan dalam penelitian ini yaitu, gelas kimia, gelas ukur, spatula, shacker, pipet tetes, buret, klem dan statif, plat tetes, neraca digital, corong, lumpang dan alu, botol semprot, Erlenmeyer dan $\mathrm{pH}$ meter.

Bahan-bahan yang digunakan pada penelitian ini yaitu, bunga tanaman kerandang, aquades, etanol (Merck), $\mathrm{HCl}$ (Merck), $\mathrm{NaOH}$ (Merck), $\mathrm{CH}_{3} \mathrm{COOH}$ (Merck), $\mathrm{NH}_{4} \mathrm{OH}$ (Merck), kertas saring, indikator fenolftalein, indikator metil orange, larutan buffer $\mathrm{pH} 1-11$ dan aluminium foil

\section{Ekstraksi Bunga Tanaman Kerandang}

10 gram bunga tanaman kerandang, dicuci dengan air sampai bersih, dipotong kecil-kecil kemudian dimasukkan kedalam Erlenmeyer ditambah pelarut etanol sebanyak $100 \mathrm{~mL}$, kemudian shaker dan dimaserasi selama 24 jam. Ekstrak kemudian disaring. Hasil peyaringan siap digunakan sebagai indikator asam basa.
Pengujian Warna pada Larutan Asam dan Basa

3 tetes ekstrak bunga kerandang yang diperoleh diuji dengan cara diteteskan ke dalam larutan $\mathrm{HCl} 0,1 \mathrm{M}, \mathrm{NaOH} 0,1 \mathrm{M}, \mathrm{NH}_{4} \mathrm{OH} 0,1 \mathrm{M}$ dan $\mathrm{CH}_{3} \mathrm{COOH} \quad 0,1$ M. Kemudian diamati perubahan warnanya (Rahmawati, dkk., 2016).

\section{Pengujian Warna pada Larutan Buffer Phosfat}

5 tetes larutan buffer ke dalam plat tetes sebanyak dengan $\mathrm{pH}$ yang berbeda-beda yaitu $\mathrm{pH}$ 1, 3, 5, 7 dan 11. Kemudian ditambahkan dengan ekstrak bunga tanaman kerandang sebanyak 3 tetes ke dalam masing-masing larutan buffer. Selanjutnya dicatat perubahan warna yang terjadi (Nuryanti, $\mathrm{dkk}, 2010)$.

\section{Pengujian Pada Titrasi Asam-Basa}

\section{Titrasi Asam Kuat-Basa Kuat}

20 mL larutan $\mathrm{HCl} 0,1 \mathrm{~N}$, lalu dimasukkan dalam Erlenmeyer, kemudian ditambahkan 3 tetes ekstrak bunga tanaman kerandang hingga larutan berubah warna. Dititrasi dengan larutan $\mathrm{NaOH} 0,1$ $\mathrm{N}$ hingga terjadi perubahan warna. Titrasi dilakukan sebanyak 3 kali. Volume titer yang digunakan dicatat. Setiap $2 \mathrm{~mL}$ titer yang digunakan, diukur nilai pH-nya hingga terjadi perubahan warna. Selanjutnya, titrasi ini diganti dengan mengganti ekstrak tanaman kerandang sebagai indikator dengan fenolftalein untuk pembanding (Nuryanti, dkk., 2010).

\section{Titrasi Asam Lemah-Basa Kuat}

$20 \mathrm{~mL}$ larutan $\mathrm{CH}_{3} \mathrm{COOH} 0,1 \mathrm{M}$, lalu dimasukkan dalam Erlenmeyer. Ditambahkan 3 tetes ekstrak tanaman kerandang sampai larutan berubah warna, dititrasi dengan larutan $\mathrm{NaOH} 0,1$ $M$ hingga terjadi perubahan warna. Titrasi dilakukan sebanyak 3 kali. Dicatat volume titer yang digunakan. Setiap $2 \mathrm{~mL}$ titer yang digunakan, diukur nilai $\mathrm{pH}$-nya hingga terjadi perubahan warna. Selanjutnya, titrasi ini diganti dengan mengganti ekstrak tanaman kerandang sebagai indikator dengan penolftalein untuk pembanding (Nuryanti, dkk., 2010).

\section{Titrasi Basa Lemah-Asam Kuat}

$20 \mathrm{~mL}$ larutan $\mathrm{NH}_{4} \mathrm{OH} \quad 0,1 \mathrm{M}$, lalu dimasukkan dalam Erlenmeyer. Kemudian ditambahkan 3 tetes ekstrak tanaman kerandang hingga larutan berubah warna, dititrasi dengan larutan $\mathrm{HCl} \mathrm{0,1} \mathrm{M} \mathrm{hingga} \mathrm{terjadi} \mathrm{perubahan} \mathrm{warna.}$ Titrasi dilakukan sebanyak 3 kali. Dicatat volume titer yang digunakan. Setiap $2 \mathrm{~mL}$ titer yang digunakan, diukur nilai pH-nya hingga terjadi perubahan warna. Selanjutnya titrasi ini diganti dengan mengganti ekstrak tanaman kerandang sebagai indikator dengan metil orange untuk pembanding (Nuryanti, dkk., 2010).

\section{Hasil dan Pembahasan}

\section{Ekstraksi Bunga Tanaman Kerandang}

Ekstra bunga tanaman kerandang yang masih segar dimaserasi dengan menggunakan 
pelarut etanol. Ekstraksi dengan metode maserasi didasarkan pada sifat kelarutan dari komponen didalam pelarut yang digunakan (Siregar, 2009). Pemilihan etanol sebagai pelarut didasarkan pada sifat etanol yang polar yang dapat melarutkan senyawa-senyawa golongan flavonoid yang juga bersifat polar termasuk antosianin. Menurut Bridle \& Timberlake (1997) bahwa antosianin merupakan komponen yang bersifat polar sehingga pelarut yang digunakan juga harus bersifat polar. Kemudian dimaserasi disaring untuk memisahkan antara residu dan filtrate. Ekstrak yang dihasilkan berwarna hitam keunguan. Hal tersebut dapat menjadi indikasi kemungkinan di dalam tanaman kerandang terdapat pigmen antosianin karena antosianin yang berperan dalam memberi warna pada bunga, buah, dan daun tumbuhan hijau.

\section{Pengujian Warna pada Larutan Asam dan Basa}

Hasil pengujian indikator ekstrak bunga tanaman kerandang pada larutan asam dan basa memberikan perubahan warna, yakni dalam asam kuat $(\mathrm{HCl} \mathrm{0,1} \mathrm{M)} \mathrm{berwarna} \mathrm{merah,} \mathrm{dalam} \mathrm{asam}$ lemah $\left(\mathrm{CH}_{3} \mathrm{COOH} 0,1 \mathrm{M}\right)$ berwarna merah muda dan dalam basa kuat $(\mathrm{NaOH} 0,1 \mathrm{M})$ berwarna hijau serta dalam basa lemah $\left(\mathrm{NH}_{4} \mathrm{OH} 0,1 \mathrm{M}\right)$ berwarna hijau muda. Adanya kemampuan indikator bunga tanaman kerandang untuk berubah warna pada asam dan basa disebabkan oleh adanya antosianin (Lestario, dkk., 2014), yang di dalam strukturnya mengandung kation flavilium yang dapat berubah bentuk strukturnya oleh pengaruh $\mathrm{pH}$ (Nuryanti, dkk.,2010).

\section{Pengujian pada Larutan Buffer Phosfat pH 1-11}

Larutan penyangga (buffer) merupakan larutan dari asam lemah dan basa konjugatnya atau basa lemah dengan konjugatnya. Sifat utama dari larutan penyangga adalah daya tahannya terhadap perubahan $\mathrm{pH}$ akibat penambahan sejumlah kecil asam kuat atau basa kuat (Goldberg, 2003). Pengujian warna dilakukan dengan meneteskan ekstrak kulit jantung pisang kepok ke dalam larutan buffer phosfat dengan rentang $\mathrm{pH} 1$ sampai $\mathrm{pH} 11$. Hasil pengujian menunjukkan bahwa dari larutan buffer phosfat dengan $\mathrm{pH} 1$ sampai $\mathrm{pH}$ 11, ekstrak bunga tanaman kerandang memberikan 4 kelompok warna yaitu larutan buffer phosfat dengan $\mathrm{pH} 1$ berwarna merah, $\mathrm{pH} 3$ berwarna merah muda, $\mathrm{pH} 5$ sampai 9 berwarna hijau muda, dan $\mathrm{pH} 11$ berwarna biru tua. Hasil yang diperoleh ini dapat digunakan untuk mengetahui trayek $\mathrm{pH}$ dari ekstrak bunga tanaman kerandang. Karena kemampuan mata untuk membedakan warna-warni sangat terbatas, maka trayek $\mathrm{pH}$ suatu indikator dapat ditentukan menggunakan alat yang mampu membedakan panjang gelombang pada warnawarni dari indikator (Day \& Underwood, 2002). Data pengujian warna terdapat dalam Tabel 1.

Tabel 1. Hasil Pengujian Warna dalam Larutan Buffer Phosfat

\begin{tabular}{ll}
\hline \multicolumn{1}{c}{ Larutan Buffer } & \multicolumn{1}{c}{$\begin{array}{c}\text { Warna Larutan Ekstrak } \\
\text { Bunga Tanaman Kerandang }\end{array}$} \\
\hline pH 1 & Merah \\
pH 3 & Merah muda \\
pH 5 & Hijau muda \\
pH 7 & Hijau muda \\
pH 9 & Hijau muda \\
pH 11 & Biru tua \\
\hline
\end{tabular}

Berdasarkan hasil yang diperoleh, maka ekstrak kulit jantung pisang kepok dapat digunakan sebagai indikator alami dalam penentuan asam basa yang didasarkan oleh adanya perubahan warna pada setiap perubahan $\mathrm{pH}$. Terjadinya perubahan warna di dalam berbagai rentang $\mathrm{pH}$ disebabkan oleh kandungan utama zat warna pada kulit jantung pisang kepok berupa senyawa antosianin. Antosianin lebih stabil dalam media asam pada $\mathrm{pH}$ rendah dari pada dalam larutan alkali dengan $\mathrm{pH}$ tinggi (Rein, 2005). Bentuk kesetimbangan antosianin dapat dilihat pada Gambar 1.

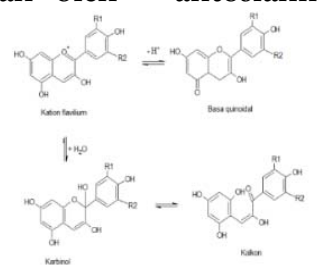

Gambar 1. Kesetimbangan antosianin dalam larutan (Rein, 2005).

Gambar 1 menjelaskan bahwa di dalam larutan terdapat empat kesetimbangan yaitu kation flavilium, basa quinoidal, karbinol, (Pseudobasa), dan kalkon dibawah $\mathrm{pH}$ rendah antosianin berada dalam bentuk kation flavilium saat $\mathrm{pH}$ dinaikkan ( $>5$ ) akan mempercepat kehilangan proton sehingga membentuk basa quinoidal yang cenderung menjadi hijau atau ungu, selain itu kenaikan $\mathrm{pH}$ menyebabkan hidrasi kation flavilium untuk membentuk karbinol (pseudobasa) atau kalkon yang tidak berwarna (Rein, 2005). Warna ekstrak antosianinbunga tanaman kerandang secara konsisten hanya dipengaruhi oleh $\mathrm{pH}$ yaitu berubah dari merah, merah muda, hijau, dan hijau muda 
seiring kenaikan $\mathrm{pH} \quad 1$ hingga $\mathrm{pH} \quad 11$ (Mahmadatussa'adah, dkk., 2014).

\section{Pengujian pada Titrasi Asam-Basa}

Titrasi Asam Kuat (HCl) - Basa Kuat (NaOH)

Pengamatan hasil titrasi asam kuat-basa kuat dapat dilihat pada Tabel 2 dan 3. Berdasarkan hasil pengamatan tersebut, pada penggunaan indikator bunga tanaman kerandang titik akhir titrasi yang diperoleh yaitu pada penambahan 19,5
$\mathrm{mL} \mathrm{NaOH} 0,1 \mathrm{M}$ dengan $\mathrm{pH}$ rata-rata 8,90 serta perubahan warna yang terjadi dari merah muda menjadi bening pada titik akhir titrasi. Indikator pembanding yang digunakan yakni indikator fenolftalein, titik akhir titrasi yang diperoleh pada penambahan 19,7 $\mathrm{mL} \mathrm{NaOH} \mathrm{0,1} \mathrm{M}$ dengan $\mathrm{pH}$ rata-rata yaitu 9,09 serta perubahan warna yang terjadi dari tidak berwarna menjadi ungu muda. Data hasil titrasi seperti dalam Tabel 2, 3, 4, 5, 6 dan 7 .

Tabel 2. Data hasil titrasi $20 \mathrm{~mL} \mathrm{HCl} \mathrm{0,1} \mathrm{M} \mathrm{dan} \mathrm{NaOH}$ 0,1 M dengan indkator ekstrak bunga tanaman kerandang

\begin{tabular}{lllllll}
\hline \multirow{2}{*}{$\mathrm{N}$} & Volume & \multicolumn{3}{c}{ Titrasi $\mathrm{ke} / \mathrm{pH}$} & $\mathrm{pH}$ rata- & \multicolumn{2}{c}{ Perubahan warna } \\
\cline { 3 - 5 } $\mathrm{o}$ & $\mathrm{NaOH}(\mathrm{mL})$ & $1 / \mathrm{pH}$ & $2 / \mathrm{pH}$ & $3 / \mathrm{pH}$ & rata & \\
\hline 1 & 0 & 2,31 & 2,38 & 2,39 & 2,36 & Merah muda \\
2 & 2 & 2,35 & 2,40 & 2,41 & 2,38 & Merah muda \\
3 & 4 & 2,41 & 2,44 & 2,43 & 2,42 & Merah muda \\
4 & 6 & 2,46 & 2,48 & 2,49 & 2,47 & Merah muda \\
5 & 8 & 2,53 & 2,54 & 2,54 & 2,53 & Merah muda \\
6 & 10 & 2,60 & 2,65 & 2,65 & 2,63 & Merah muda \\
7 & 12 & 2,68 & 2,71 & 2,72 & 2,70 & Merah muda \\
8 & 14 & 2,84 & 2,86 & 2,84 & 2,84 & Merah muda \\
9 & 16 & 3,11 & 3,28 & 3,30 & 3,23 & Merah muda \\
10 & 18 & 8,39 & 8,41 & 8,41 & 8,40 & Merah muda \\
11 & 19,7 & 8,98 & 8,87 & 8,86 & 8,90 & Bening (hamper tak berwarna) \\
12 & 20 & 9,60 & 9,58 & 9,58 & 9,58 & Tak berwarna
\end{tabular}

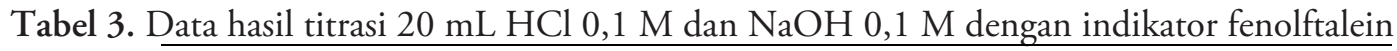

\begin{tabular}{lllllll}
\hline \multirow{2}{*}{$\mathrm{N}$} & Volume & \multicolumn{3}{c}{ Titrasi ke/pH } & $\mathrm{pH}$ rata- & \multicolumn{1}{c}{ Perubahan warna } \\
\cline { 3 - 5 } $\mathrm{o}$ & $\mathrm{NaOH}(\mathrm{mL})$ & $1 / \mathrm{pH}$ & $2 / \mathrm{pH}$ & $3 / \mathrm{pH}$ & rata & \\
\hline 1 & 0 & 2,47 & 2,49 & 2,49 & 2,48 & Tidak berwarna \\
2 & 2 & 2,56 & 2,55 & 2,51 & 2,53 & Tidak berwarna \\
3 & 4 & 2,61 & 2,61 & 2,61 & 2,61 & Tidak berwarna \\
4 & 6 & 2,65 & 2,64 & 2,62 & 2,63 & Tidak berwarna \\
5 & 8 & 2,70 & 2,71 & 2,65 & 2,68 & Tidak berwarna \\
6 & 10 & 2,76 & 2,73 & 2,72 & 2,73 & Tidak berwarna \\
7 & 12 & 2,83 & 2,83 & 2,81 & 2,82 & Tidak berwarna \\
8 & 14 & 2,92 & 2,93 & 2,94 & 2,93 & Tidak berwarna \\
9 & 16 & 3,18 & 3,22 & 3,24 & 3,21 & Tidak berwarna \\
10 & 18 & 8,80 & 8,77 & 8,78 & 8,78 & Tidak berwarna \\
11 & 19,5 & 9,09 & 9,08 & 9,10 & 9.09 & Ungu Muda \\
12 & 20 & 9,59 & 9,60 & 9,62 & 9,60 & Ungu \\
\hline
\end{tabular}

Secara teori rentang $\mathrm{pH}$ perubahan indikator fenolftalein berada pada kisaran 8,0-9,6 (Day \& Underwood, 2002). Hal tersebut membuktikan bahwa rentang $\mathrm{pH}$ perubahan warna ekstrak kulit jantung pisang kepok masih berada pada rentang perubahan $\mathrm{pH}$ indikator fenolftalein. Hasil dari penggunaan indikator kulit jantung pisang kepok dan indikator fenolftalein sebagai pembanding dapat dilihat pada kurva yang terdapat pada Gambar 2.

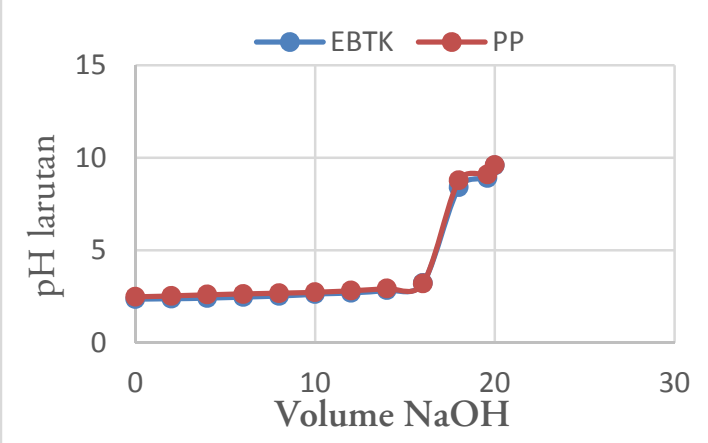


Gambar 2. Kurva titrasi asam kuat $(\mathrm{HCl})$ - basa kuat $(\mathrm{NaOH})$

Dari gambar kurva diatas, memperlihatkan Kurva titrasi asam kuat-basa kuat yang menggunakan indikator bunga tanaman kerandang dengan indikator fenolftalein sebagai pembanding, bahwa pada penambahan $\mathrm{NaOH} \quad 0,1$ M dari volume $0 \mathrm{~mL}$ sampai $20 \mathrm{~mL}$ kedua garis kurva cenderung berhimpitan menunjukkan bahwa nilai $\mathrm{pH}$ yang diperoleh dari kedua indikator tersebut tidak jauh berbeda. Kurva yang dihasilkan dari kedua indikator tidak memiliki perbedaan yang signifikan. Hal tersebut mengindikasikan bahwa penggunaan indikator bunga tanaman kerandang dapat digunakan untuk titrasi asamkuat-basa kuat.

\section{Titrasi Asam Lemah $\left(\mathrm{CH}_{3} \mathrm{COOH}\right)$ - Basa Kuat $(\mathrm{NaOH})$}

Pengamatan hasil titrasi asam lemah-basa kuat dapat dilihat pada Tabel 4 dan 5. Berdasarkan hasil pengamatan tersebut, untuk penggunaan indikator bunga tanaman kerandang di peroleh titik akhir titrasi pada penambahan $19,8 \mathrm{~mL} \mathrm{NaOH} 0,1$ $\mathrm{M}$ dengan $\mathrm{pH}$ rata-rata 9,22 serta perubahan warna yang terjadi dari coklat muda menjadi bening kecoklatan pada titik akhir titrasi. Untuk indikator pembanding yakni indikator fenolftalein, titik akhir titrasi yang diperoleh yaitu pada penambahan 19,2 $\mathrm{mL} \mathrm{NaOH} 0,1 \mathrm{M}$ dengan $\mathrm{pH}$ rata-rata 9,23 serta perubahan warna yang terjadi dari tidak berwarna menjadi ungu muda.

Tabel 4. Data titrasi $20 \mathrm{~mL}$ larutan $\mathrm{CH}_{3} \mathrm{COOH}$ 0,1 M dan $\mathrm{NaOH}$ 0,1 $\mathrm{M}$ dengan indikator ekstrak bunga tanaman kerandang

\begin{tabular}{lllllll}
\hline \multirow{2}{*}{$\mathrm{N}$} & Volume & \multicolumn{3}{c}{ Titrasi ke/pH } & \multirow{\mathrm{pH}\text{rata-}}{*}{ Perubahan warna } \\
\cline { 3 - 5 } $\mathrm{o}$ & $\mathrm{NaOH}(\mathrm{mL})$ & $1 / \mathrm{pH}$ & $2 / \mathrm{pH}$ & $3 / \mathrm{pH}$ & rata & \\
\hline 1 & 0 & 3,46 & 3,45 & 3,47 & 3,46 & Merah muda \\
2 & 2 & 3,96 & 3,93 & 3,95 & 394 & Merah muda \\
3 & 4 & 4,20 & 4,21 & 3,21 & 4,20 & Merah muda \\
4 & 6 & 4,40 & 4,41 & 4,41 & 440 & Merah muda \\
5 & 8 & 4,59 & 4,59 & 4,58 & 4,58 & Merah muda \\
6 & 10 & 4,76 & 4,76 & 4,80 & 4,76 & Merah muda \\
7 & 12 & 4,95 & 4,95 & 4,94 & 4,94 & Merah muda \\
8 & 14 & 5,12 & 5,16 & 5,15 & 5,14 & Merah muda \\
9 & 16 & 5,48 & 5,49 & 5,45 & 5,47 & Merah muda \\
10 & 18 & 6,19 & 6,31 & 6,23 & 6,24 & Merah muda \\
11 & 19,8 & 9,13 & 9,13 & 9,23 & 9.22 & Bening kemerahan \\
12 & 20 & 10,56 & 10,63 & 10,59 & 10,59 & Bening \\
\hline
\end{tabular}

Tabel 5. Data titrasi $20 \mathrm{~mL}$ larutan $\mathrm{CH}_{3} \mathrm{COOH} 0,1 \mathrm{M}$ dan $\mathrm{NaOH}$ 0,1 $\mathrm{M}$ dengan indikator fenolftalein

\begin{tabular}{lllllll}
\hline & Volume & \multicolumn{3}{c}{ Titrasi ke/pH } & & Perubahan \\
\cline { 3 - 5 } No & $\begin{array}{c}\mathrm{NaOH} \\
\text { warna }\end{array}$ & $1 / \mathrm{pH}$ & $2 / \mathrm{pH}$ & $3 / \mathrm{pH}$ & $\mathrm{pH}$ rata-rata & \\
\hline 1 & 0 & 3,45 & 3,45 & 3,46 & 3,45 & Tidak berwarna \\
2 & 2 & 3,95 & 3,94 & 3,95 & 3,94 & Tidak berwarna \\
3 & 4 & 4,19 & 4,19 & 4,18 & 4,18 & Tidak berwarna \\
4 & 6 & 4,39 & 4,40 & 4,41 & 4,40 & Tidak berwarna \\
5 & 8 & 4,52 & 4,56 & 4,53 & 4,53 & Tidak berwarna \\
6 & 10 & 4,71 & 4,75 & 4,74 & 4,73 & Tidak berwarna \\
7 & 12 & 4,90 & 4,94 & 4,95 & 4,93 & Tidak berwarna \\
8 & 14 & 5,11 & 5,12 & 5,12 & 5,11 & Tidak berwarna \\
9 & 16 & 5,45 & 5,42 & 5,44 & 5,43 & Tidak berwarna \\
10 & 18 & 6,15 & 6,10 & 6,14 & 6,13 & Tidak berwarna \\
11 & 19,4 & 9,18 & 9,20 & 9,25 & 9,23 & Ungu Muda \\
12 & 20 & 10,46 & 10,50 & 10,50 & 10,48 & Ungu \\
\hline
\end{tabular}

Hasil penggunaan indikator kulit jantung pisang kepok dengan indikator fenolftalein sebagai pembanding dapat dilihat pada kurva yang terdapat pada Gambar 3. 


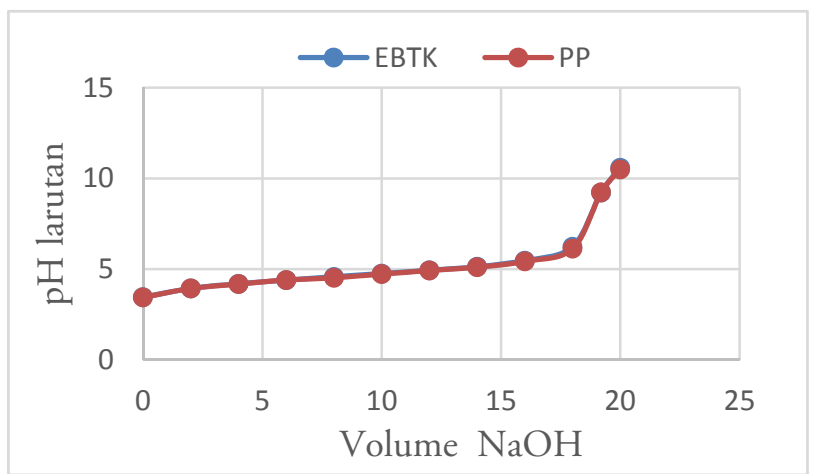

Gambar 3. Kurva titrasi asam lemah $\left(\mathrm{CH}_{3} \mathrm{COOH}\right)$ - basa kuat $(\mathrm{NaOH})$

Dari Kurva titrasi asam lemah-basa kuat yang menggunakan indikator bunga tanaman kerandang dengan indikator pembanding yaitu indikator fenolftalein menunjukkan bahwa nilai $\mathrm{pH}$ dari ke dua indikator tersebut tidak terlalu jauh berbeda. Berdasarkan kurva tersebut, nilai $\mathrm{pH}$ dari kedua indikator pada penambahan $0 \mathrm{~mL}$ sampai 20 $\mathrm{mL} \mathrm{NaOH} \mathrm{0,1} \mathrm{M} \mathrm{cenderung} \mathrm{berimpitan} \mathrm{sehingga}$ hasilnya tidak jauh berbeda. Hal tersebut mengindikasikan bahwa indikator daun wungu dapat digunakan dalam titrasi asam lemah-basa kuat.

Titrasi basa lemah $\left(\mathrm{NH}_{4} \mathrm{OH}\right)$ - asam kuat $(\mathrm{HCl})$

Data hasil pengamatan titrasi basa lemahasam kuat dapat di lihat pada Tabel 6 dan 7 .
Berdasarkan data tersebut, untuk penggunaan indikator bunga tanaman kerandang diperoleh titik akhir titrasi pada penambahan 19,4 $\mathrm{mL} \mathrm{HCl} \mathrm{0,1} \mathrm{M}$ dengan $\mathrm{pH}$ rata-rata 2,77 serta perubahan warna dari hijau menjadi merah. Pada indikator pembanding yang di gunakan yaitu indikator metil orange, diperoleh titik akhir titrasi pada penambahan $19,5 \mathrm{~mL} \mathrm{HCl}$ dengan $\mathrm{pH}$ rata-rata 2,77 serta perubahan warna dari orange menjadi merah. Secara teori rentang $\mathrm{pH}$ indicator metil orange adalah 3,1-4,4 (Day \& Underwood, 2002). Data hasil titrasi seperti dalam Tabel 6 dan 7 .

Tabel 6. Data titrasi larutan $\mathrm{NH}_{4} \mathrm{OH} 0,1 \mathrm{M}$ dan $\mathrm{HCl}$ 0,1 M dengan indikator ekstrak tanaman kerandang

\begin{tabular}{lllllll}
\hline \multirow{2}{*}{ No } & Volume & \multicolumn{3}{c}{ Titrasi ke/pH } & pH rata- & $\begin{array}{c}\text { Perubahan } \\
\text { warna }\end{array}$ \\
\cline { 3 - 5 } & $\mathrm{HCl}(\mathrm{mL})$ & $1 / \mathrm{pH}$ & $2 / \mathrm{pH}$ & $3 / \mathrm{pH}$ & rata & wijau \\
\hline 1 & 0 & 9,20 & 9,17 & 9,16 & 9,18 & Hijau \\
2 & 2 & 8,82 & 8,84 & 8,81 & 8,83 & Hijau \\
3 & 4 & 8,60 & 8,63 & 8,64 & 8,62 & Hijau \\
4 & 6 & 8,43 & 8,45 & 8,46 & 8,44 & Hijau \\
5 & 8 & 8,23 & 8,24 & 8,26 & 8,24 & Hijau \\
6 & 10 & 7,96 & 7,90 & 7,95 & 7,93 & Hijau \\
7 & 12 & 6,99 & 6,95 & 6,92 & 6,95 & Hijau \\
8 & 14 & 5,80 & 5,78 & 5,76 & 5,78 & Hijau \\
9 & 16 & 3,87 & 3,87 & 3,88 & 3.87 & Hijau \\
10 & 18 & 3,81 & 3,80 & 3,82 & 3,81 & Hijau \\
11 & 19,6 & 2,78 & 2,76 & 2,78 & 2,77 & Merah muda \\
12 & 20 & 2,72 & 2,74 & 2,73 & 2,73 & Merah muda \\
\hline
\end{tabular}

Tabel 7. Data titrasi $20 \mathrm{~mL}_{\text {larutanNH}} \mathrm{N}_{4} \mathrm{OH}$ 0,1 M dan $\mathrm{HCl}$ 0,1 M dengan indikator metil orange

\begin{tabular}{lllllll}
\hline \multirow{2}{*}{ No } & Volume & \multicolumn{2}{l}{ Titrasi ke/pH } & $\mathrm{pH}$ rata- & $\begin{array}{l}\text { Perubahan } \\
\text { warna }\end{array}$ \\
\cline { 3 - 4 } & $\mathrm{HCl}(\mathrm{mL})$ & $1 / \mathrm{pH}$ & $2 / \mathrm{pH}$ & $3 / \mathrm{pH}$ & rata & Orange \\
\hline 1 & 0 & 9,16 & 9,16 & 9,17 & 9,16 & Orane \\
2 & 2 & 8,82 & 8,82 & 8,81 & 8,81 & Orange \\
3 & 4 & 8,60 & 8,63 & 8,64 & 8,62 & Orange \\
4 & 6 & 8,43 & 8,45 & 8,46 & 8,44 & Orange \\
5 & 8 & 8,23 & 8,24 & 8,26 & 8,24 & Orange \\
6 & 10 & 7,96 & 7,90 & 7,95 & 7,93 & Orange \\
7 & 12 & 6,95 & 6,95 & 6,92 & 6,95 & Orange \\
8 & 14 & 5,82 & 5,78 & 5,76 & 5,70 & Orange \\
9 & 16 & 3,84 & 3,87 & 3,88 & 3.86 & Orange \\
10 & 19,5 & 3,81 & 3,84 & 3,83 & 3,82 & Orange \\
11 & 20 & 2,78 & 2,76 & 2,79 & 2,77 & Merah muda \\
\hline
\end{tabular}


Dari data tersebut terlihat bahwa $\mathrm{pH}$ ratarata ekstrak bunga tanaman kerandang berada pada rentang $\mathrm{pH}$ indikator metil orange. Sehingga ekstrak bunga tanaman kerandang baik untuk digunakan sebagai indikator titrasi basa lemah dan asam kuat. Metil orange merupakan indikator sintesis dengan rentang $\mathrm{pH} 3,1-4,4$ (Day \& Underwood, 2002). Hasil penggunaan bunga tanaman kerandang dengan indikator metil orange sebagai pembanding dapat dilihat pada kurva yang terdapat pada Gambar 4.

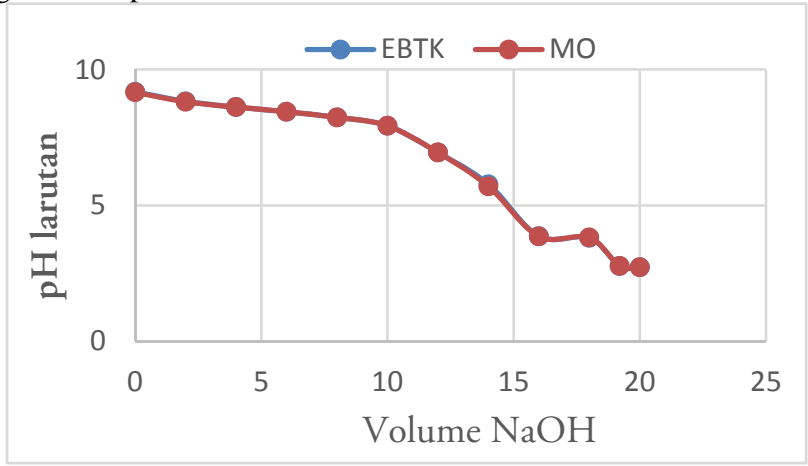

Gambar 4. Kurva titrasi basa lemah $\left(\mathrm{NH}_{4} \mathrm{OH}\right)$ - asam kuat $(\mathrm{HCl})$.

Berdasarkan hasil ketiga pasangan kurva titrasi tersebut, terlihat bahwa ekstrak bunga tanaman kerandang hampir sama dengan indikator fenolftalein dalam hal penggunaannya sebagai indikator. Rentang $\mathrm{pH}$ indikator fenolftalein berada pada kisaran 8,0-9,6 perubahan warna dari tidak berwarna menjadi berwarna ungu (Day \& Underwood, 2002). Pada titrasi asam kuat dan basa kuat dengan ekstrak bunga tanaman kerandang berubah pada kisaran $\mathrm{pH}$ 8,40-8,90 perubahan warna terjadi dari merah muda menjadi bening, sedangkan pada titrasi asam lemah dan basa kuat ekstrak bunga tanaman kerandang berubah pada kisaran pH 6,24-9,22. Selanjutnya pada titrasi asam kuat dan basa lemah untuk indikator metil orange dengan rentang $\mathrm{pH} 3,1-4,4$ perubahan warna yang terjadi dari kuning-merah (Day dan Underwood, 2002) dan ekstrak bunga tanaman kerandang berada pada rentang $\mathrm{pH}$ 3,81-2,77 dengan perubahan warna dari hijau menjadi merah muda.

\section{Kesimpulan}

Ekstrak bunga tanaman kerandang dapat digunakan sebagai indikator asam-basa. Indikator ekstrak bunga tanaman kerandang mempunyai kemiripan dengan indikator metil orange, sehingga dapat sebagai alternatif pengganti indikator tersebut dan dapat diaplikasikan sebagai indikator pada titrasi asam-basa tepatnya pada titrasi basa lemahaasa kuat.

\section{Ucapan Terima Kasih}

Ucapan terima kasih penulis sampaikan kepada teman-teman yang sudah membantu penelitian ini, Husnia dan Tasrik laboran laboratorium kimia FKIP UNTAD, yang telah memberikan bimbingan dan masukan dalam menyelesaikan penelitian ini.

\section{Referensi}

Abbas, S. K. (2012). Study of acid-base indicator property of flowers of ipomoea boliba.
International Current Pharmaceutical Journal, (12), 420-422.

Agrawal, S., Raj, N. R., Chouan, K., Raj, C. N., Jain, S., \& Balasubramaniam, A. (2011). Isolation of herbal acid-base indicator from the seeds of punicagranatum. Journal Chemical Pharmaceutical Research, 3(2), 168171.

Arja, F. S., Darwis, D., \& Santoni, A. (2013). Isolasi, identifikasi, dan uji antioksidan senyawa antosianin dari buah sikaduduk (Melastoma malabathricum L.) serta aplikasi sebagai pewarna alami. Jurnal Kimia Unand, 2(1), 124-127.

Bridle, P., \& Timberlake, C. F, (1997). Anthocyanins as natural food colours selected aspects. Food Chemistry, 58(1), 103-109

Day, R. A., \& Underwood, A. L. (2002). Analisis kimia kuantitatif. Jakarta: Erlangga.

Durst, R. W. \& Wrolstad, R. E. (2005). Characterization and measurement of anthocyanins by uv-visible spectroscopy in r. e. wrolstad (ed) handbook of analytical food chemistry. New York: John Wiley \& Sons.

Frantauansyah., Nuryanti, S., \& Hamzah, B. (2013). Ekstrak bunga waru (hibiscus tiliaceus) sebagai indikator asam-basa. Jurnal Akademika Kimia, 2(1), 11-16.

Goldberg, E. D. (2003). Schaum's easy outlines kimia untuk pemula. Jakarta: Erlangga.

Hizbul, M. E., Yuliyanto, \& Retnoyuanni, M. (2008). Pemanfaatan bunga tapak dara sebagai alternatif pembuatan indikator ph asam basa. Pelita-Jurnal Penelitian Mahasiswa UNY, (1), 1-11.

Indira, C. (2015). Pembuatan indikator asam basa karamunting. Jurnal Kaunia, 11(1), 1-10. 
Irwan., Supriadi., \& Sakung, J. (2014). Identifikasi flavonoid pada ekstrak bunga kembang merak (caesalpinia pulcherrima). Jurnal Akademika Kimia, 3(2), 295-300.

Izonfuo, L. T., Fekamhorhobo, G. K., Obomanu, G. K., \& Daworiye, L. T., (2006). Acid base indikator properties of dye from local plant: Bassella alba and Hibiscus sabdariffa. Journal of Applied Sciences and Environmental Managemen, 10(1), 5-8.

Kurniawati, Mappiratu, \& Ahmad, R. (2015). Kajian ekstrak etanol bunga tanaman johar (cassia siamea l) sebagai bioindikator asam basa. Natural Science, 4(2), 128-143.

Lestario, L. N., Yoga, M. K. W. C., \& Kristijanto, A. I. (2014). Stabilitas antosianin jantung pisang kepok (Musa paradisiaca L.) terhadap cahaya sebagai pewarna agar-agar. Jurnal Agritech, 34(4), 374-381.

Mahmadatussa'adah, A., Fardiaz, D., Andarwulan, N., \& Kusnandar, F. (2014). Karakteristik warna dan aktivitas antioksidan antosianin ubi jalar ungu. Jurnal Teknologi dan Industri Pangan, 25(2), 176-184.

Marwati, S. (2010). Aplikasi beberapa ekstrak bunga berwarna sebagai indikator alami pada titrasi asam basa. Prosiding Seminar Nasional Penelitian,Pendidikan dan Penerapan MIPA. Yogyakarta: FMIPA UNY.
Maryanti, E., Trihadi, B., \& Ikhwanuddin. (2011). Pemanfaatan ekstrak bunga mawar merah (rosa hibrida bifera) sebagai indikator pada titrasi asam basa. Jurnal Gradien, 7(2), $697-$ 701.

Mulyono, H. A. M. (2010). Membuat reagen kimia di laboratorium. Jakarta: Bumi Aksara.

Nuryanti, S., Matsjeh, S., Anwar, C., \& Raharjo, T. J. (2010). Indikator titrasi asam-basa dari ekstrak bunga sepatu (Hibiscus Rosa Sinensis l). Jurnal AGRITECH, 30(3), 178-183.

Pimpodkar, N., Bishe, S. H., \& Surve, H, B. (2014). Use of bixaorellana fruit extract as a natural indicator in acid base tration. International Journal for Pharmaceutical Research Scholars (IJPRS), 3(11), 156-159.

Rahmawati., Nuryanti, S., \& Ratman. (2016). Indikator asam-basa dari bunga dadap merah. Jurnal Akademika Kimia, 5(1), 29-36.

Rein, M. (2005). Copigmentation reactions and color stability of berry anthocyanins. Unpublished doctoral dissertation, Helsinki: University of Helsinki.

Siregar, Y. D. I. (2009). Pembuatan kertas indikator asam basa dari bunga kembang sepatu (Hibiscus rosa-sinensis L.). Jurnal Kimia Valensi, 1(5), 246-251. 